Man and Nature

L'homme et la nature

\title{
Marivaux's 'Libertinage d'Idées' in Le Spectateur Français
}

\section{Richard M. Chadbourne}

Volume 8, 1989

URI : https://id.erudit.org/iderudit/1012598ar

DOI : https://doi.org/10.7202/1012598ar

Aller au sommaire du numéro

Éditeur(s)

Canadian Society for Eighteenth-Century Studies / Société canadienne d'étude du dix-huitième siècle

ISSN

0824-3298 (imprimé)

1927-8810 (numérique)

Découvrir la revue

Citer cet article

Chadbourne, R. M. (1989). Marivaux's 'Libertinage d'Idées' in Le Spectateur Français. Man and Nature / L'homme et la nature, 8, 73-80.

https://doi.org/10.7202/1012598ar

Copyright (c) Canadian Society for Eighteenth-Century Studies / Sociéte canadienne d'étude du dix-huitième siècle, 1989
Ce document est protégé par la loi sur le droit d'auteur. L'utilisation des services d'Érudit (y compris la reproduction) est assujettie à sa politique d'utilisation que vous pouvez consulter en ligne.

https://apropos.erudit.org/fr/usagers/politique-dutilisation/ 


\section{Marivaux's 'Libertinage d'Idées' in Le Spectateur Français}

In 1717 Pierre de Marivaux, then thirty years old, whose slight reputation rested on his publication of 'burlesque' novels parodying classical forms and a mock epic in verse, published in Le Nouveau Mercure a brief series of articles entitled Lettres sur les habitants de Paris. ${ }^{1}$ These first essays of his, inspired by Charles Dufresny's Amusements sérieux et comiques d'un Siamois and to a lesser extent by La Bruyère's Caractères, are less interesting for what they say about aspects of Parisian life than for certain critical statements concerning the form he intends to adopt. These statements do nothing less than foreshadow the esthetics he was later to put into practice in his essay masterpiece, Le Spectateur Français.

In the first such declaration, 'Avant-propos du Théophraste moderne,' he insists on 'la quantité de matières ... et leur variété,' 'le mélange du sérieux et du gai,' and '1'ordre dans la distribution des sujets.' Order will depend heavily on chance, 'le hasard.' 'J'adresse cette relation,' he says, 'à une dame qui me l'avait demandée ... Je commence par lui parler des choses qui se passaient quand je fis cette relation. Je continue au hasard, et je finis quand il me plaît. ${ }^{2}$ As for the relationship promised with his reader, he intends both to please his reader and, at the risk of displeasing his reader, sometimes merely to please himself. He is willing to take the chance that the cultivated reader here represented by the fictional 'Madame ${ }^{* * * \prime}$ to whom he addresses these public letters-will respond to the kind of dialogue he is introducing.

He concludes the foreword thus: 'Cet ouvrage, en un mot, est la production d'un esprit libertin, qui ne se refuse rien de ce qui peut l'amuser en chemin faisant. J'espère que le lecteur n'y perdra rien.' Marivaux appears to be using the word 'libertin' here in the sense defined by Gaston Cayrou in his Le Français Classique: '1'homme honnêtement indépendant qui n'écoute que sa fantaisie ... qui hait la contrainte, qui suit sa pente naturelle' ${ }^{3}$

In the second critical statement I wish to summarize, 'Lettre écrite par M. de Marivaux à l'auteur du Mercure,' he distances himself from La Bruyère, rejecting as too heavy and compromising a burden the title of 'Théophraste moderne' that some would confer on him - 'moi dont 
tous les petits ouvrages sont nés du caprice; moi qui, sans m'embarrasser des lecteurs qu'ils auraient, voulus me satisfaire en les faisant, et n'eus d'autre objet que moi-même ....' ${ }^{4}$

Before turning to Le Spectateur Français, a brief look at Marivaux's Pensées sur différents sujets published in Le Nouveau Mercure in 1719, will reveal still another concept that throws light on his esthetics of the essay. This is the notion of 'le sublime de la nature,' as contrasted with 'le sublime de l'homme.' Nature's 'sublime,'

est une exposition du sujet rendu tel que l'esprit l'a vu, rendu dans l'audace et le feu de la perception, dans cet indivisible tissu des parties; ... tissu dont nous ne connaissons pas la façon, qui se fait en nous, non par nous; sur qui l'âme a comme empreint son caractère, et qui est enfin le fruit de la liberté que nous lui laissons. ${ }^{5}$

Marivaux's 'sublime de la nature,' as Frédéric Deloffre and Michel Gilot, the editors of his Journaux for Garnier, point out, anticipates Diderot's concept of l'enthousiasme. ${ }^{6}$ It is an idea with far-reaching implications for all Marivaux's work, theatre and novel as well as essay. Essentially it subordinates finished, polished, consciously controlled thought to thought-in-process, 'thought taking shape under our eyes' ('une pensée qui s'élabore sous nos yeux' as Deloffre phrases it). ${ }^{7}$ No less than Montaigne himself, with whose genius Marivaux has a deep affinity, had considered this power to render thought in the making to be one of the chief advantages and virtues of the essay.

Only a few years later, beginning in 1721 when he was but thirtyfour years old and concluding in 1724, Marivaux published a kind of 'one-man journal' in twenty-five issues or feuilles, to which he gave the title Le Spectateur Français. He was indebted, as is well known, to Addison's and Steele's Spectator, which had appeared in England from 1711 to 1714 and had been translated into French as early as 1714 under the title of Le Spectateur ou le Socrate moderne. Imitator and innovator; more innovator than imitator, according to Edward Baldwin whose detailed comparison of Spectator and Spectateur, together with the notes in the Garnier edition, shed the greatest light on the subject. ${ }^{8}$ What Marivaux seems to have valued most in The Spectator, what he was prepared to profit from by virtue of his own propensity to unconventional forms outside the classical hierarchy, was The Spectator's freedom of form. This very freedom allowed him to go his own way.

The opening four paragraphs of the First Issue serve as a kind of prologue to the work as a whole and therefore deserve to be examined in some detail. 
The first paragraph is reminiscent of the 'Au lecteur' with which Montaigne introduces his Essais. 'Lecteur, je ne veux point vous tromper, et je vous avertis d'avance que ce n'est point un auteur que vous allez lire ici. ${ }^{\prime 9}$ An author is one who sets out deliberately to think about certain subjects. Since his choice of thoughts is arbitrary, there will inevitably be something artificial, a sacrifice of naturalness or spontaneity ('naïveté' is the word Marivaux uses), in the way they are linked together. Why not, he asks, 'penser en hommes'? ${ }^{10}$ Here, as Deloffre and Gilot point out, he is echoing Pascal's famous pensée 'Quand on voit le style naturel, on est tout étonné et ravi, car on s'attendait de voir un auteur, et on trouve un homme. ${ }^{11}$ But as they also point out, Marivaux takes Pascal's concept a step further to make it serve his esthetics of the essay: he extends it beyond style to 'la composition, au sens le plus large du terme; ${ }^{\prime 12}$ in other words, he applies it to the essay structure as a whole. Furthermore, by asking 'Ne serait-il pas curieux de nous voir penser en hommes?' he is thinking not only of how we can write more naturally but also of the pleasure to be derived from 'seeing ourselves' engaged in the process - an idea that links up with 'le sublime de la nature' as expressed in his earlier Pensées sur différents sujets.

In the second paragraph Marivaux goes on to defend the role of 'chance' ('le hasard') in the writing process. 'Je ne sais point créer,' he confesses,

je sais seulement surprendre en moi les pensées que le hasard me fait ... car mon dessein n'est de penser ni bien ni mal, mais simplement de recueillir fidèlement ce qui me vient d'après le tour d'imagination que me donnent les choses que je vois ou que j'entends. ${ }^{13}$

On this point Mario Mattuci comments 'The French Spectator will give us something new and different, life as reflected by a particular tour d'imagination. ${ }^{\prime 14}$

After reassuring his readers, in the third paragraph, that far from boring them, such a way of thinking would reveal to them 'une autre sorte d'esprit, de délicatesse et de force,' Marivaux concludes this prologue with a two-line paragraph stating that what he has said up to this point, in itself, ' $n$ 'est aussi qu'une réflexion que le hasard $m$ 'a fournie.' In this way, he leads into the first of two anecdotes that will constitute the main body of this First Issue: 'Je viens de voir un homme qui attendait un grand seigneur dans sa salle, etc.' Thus the theory of le naturel, le hasard, and le tour d'imagination passes without delay into practice and illustration. ${ }^{15}$ 
Space will not permit my giving a detailed demonstration of how Marivaux applies his esthetics in Le Spectateur; but it will allow me to sketch very broadly the main features of his literary libertinage.

Again and again he returns to the defense and the expression of $l e$ naturel. His intention is to give us 'le portrait de l'esprit humain dans sa figure naturelle 16 - a phrase worthy of Montaigne. Counselling a would-be writer, he advises 'qu'il abandonne son esprit à son geste naturel. ${ }^{\prime 17}$ To write naturally - 'écrire naturellement' - is not to follow the style of such and such Ancient or Modern, but 'se ressembler fidèlement à soi-même.' To think naturally 'c'est rester dans la singularité d'esprit qui nous est échue,' for 'ainsi que chaque visage a sa physionomie, chaque esprit aussi porte une différence qui lui est propre. ${ }^{18}$

A further trait of the essayist's libertinage d'esprit, foreshadowed, as we saw, in his Lettres sur les habitants de Paris, is the freedom and unconventionality of his relationship with his reader. He seems, paradoxically, to be both indifferent to his reader and anxious to engage his reader in dialogue. 'Je ne cherche ici qu'à m'occuper moi-même,' he writes in the Twenty-Fourth Issue, returning to his journal after a silence of eight months. ${ }^{19}$ Yet it is obvious that his purpose professed earlier, in the Lettres sur les habitants de Paris, 'instruire ou divertir, ${ }^{\prime 20}$ to instruct as well as to please his readers (a more or less classical formula) has not been completely abandoned. How can we explain this apparent contradiction? Apart from the fact that he may be engaging here, like his great predecessors, Montaigne and Saint-Evremond, both of whose works he knew well, in play with his readers, in the essayist's pose of indifference to his readers, his attitude is best clarified, I believe, in the light of the special kind of dialogue with his readers which is central to both his essays and his novels. As Giovanni Bonaccorso has pointed out, Marivaux's 'réflexions' 'sont présentées par touches successives, permettant à l'écrivain de mieux préciser sa pensée, comme $s^{\prime}$ il avait devant lui un interlocuteur. ${ }^{21}$ A new relationship between author and reader had developed in his time, casting aside traditional politeness toward the reader or the desire to win his sympathy. ${ }^{22}$ Marivaux, for example, provokes the reader, anticipates criticisms, answers critics whose objections he is hearing in salons and cafés. This approach becomes an essential part of his manner first in his journals, before being assimilated into his two great novels, La Vie de Marianne and Le Paysan parvenu.

The esthetics of variety and of apparent randomness he professed earlier is fully realized in Le Spectateur. There is much less sequentiality between issues than in The Spectator. Marivaux's trademark is the sudden interruption and change of subject, the unfulfilled promise of 
subjects to be treated later. Borrowing an expression from music, he writes:

Je ne destine aucun caractère à mes idées; c'est le hasard qui leur donne le ton; de là vient qu'une bagatelle me jette parfois dans le sérieux, pendant que l'objet le plus grave me fait rire; et quand j'examine, après, le parti que mon imagination a pris, je vois souvent qu'elle ne s'est point trompée. ${ }^{23}$

At one point he recalls a subject he had promised to treat, only to announce that he is postponing it (he in fact never returns to it): 'Je me sens aujourd'hui dans un libertinage d'idées qui ne peut s'accommoder d'un sujet fixe.' (The 'Glossaire' in the Garnier edition quotes Littré on this usage of the word 'libertinage': 'Caractère de ce qui va à l'aventure,' that is, following one's fancy, proceeding at random. $)^{24}$

The need for variety is not the only, perhaps not even the most important, reason Marivaux so often interrupts the tales that garnish a large part of his essays. A more significant reason is his need to reflect upon these stories, and this may help explain why so many are unresolved or simply unfinished. In other words, the telling of a story is not an end in itself but the means to reflection. 'J'interromps souvent mon histoire, mais je l'écris moins pour la donner que pour réfléchir. ${ }^{25}$ The loose structure, full of fortuitous, unforeseen elements and discontinuities, which we find in Marivaux's fiction as well as in his essays stems, according to Jean Ehrard, from the tradition of the picaresque novel, which Marivaux had imitated in his Télémaque traves$t i{ }^{26}$ From the same source may derive also, in Ehrard's opinion, his indifference about concluding, since no internal necessity governs this type of narrative or imposes an ending upon it; it is by definition 'décousu et indéterminé.'27

Numerous attempts have been made to explain Marivaux's penchant for discontinuity in his composition. Jean Rousset attributes it to his fondness for 'les surprises de l'improvisation, ${ }^{28}$ the pleasure he experienced from receiving from each moment what it brings. Robert Mauzi relates it to his view of inconstancy in love: 'L'inconstance est à l'amour ce que l'improvisation est à l'invention littéraire. ${ }^{29}$ For Deloffre and Gilot it is not inconstancy in love but the coquettish play of author with reader that explains the alternating rhythm of giving and withholding subject matters which is so marked a feature of $L e$ Spectateur. ${ }^{30}$ The multiple, ever-changing forms of thought in Marivaux, the quality he called, in an early burlesque novel, 'la bigarrure,'31 not only give him pleasure but also, more importantly, serve as the instrument of his quest for the truth about himself and others. 'Un peu 
de bigarrure me divertit. Suivez-moi, mon cher Lecteur. A vous dire le vrai, je ne sais pas bien où je vais; mais c'est le plaisir du voyage. ${ }^{\prime 32}$

For Georges Poulet, probing more deeply the mind of this writer who said of himself in Le Spectateur, 'Je fais le philosophe ici,' and who invented what one of his contemporaries called 'la métaphysique du coeur, ${ }^{\prime 33}$ there is an 'existentialist' turn, avant la lettre, to Marivaux's doubt about the possibility of establishing the essence of human nature, his resignation to the irremediable contingency to which human life is subject. Poulet compares Marivaux's character's losing the thread of his discourse to his losing 'le fil de sa propre existence. ${ }^{34}$ Without ever giving up hope in recovering the continuity of his life, he accepts in the meantime 'le délicieux désordre ${ }^{35}$ of his being - his existence, I should say - living from moment to moment, open to the creative possibilities that le hasard provides him with. Poulet does not fail to make the obvious connection between this view of life - at once a philosophy, a moral stance, and an esthetics - and the very similar view that underlies the essays of Marivaux's great predecessor, Montaigne. ${ }^{36}$

\section{Conclusion}

In defending the feuille périodique, a genre reputed in his day to be minor as well as frivolous, Marivaux was subverting the hierarchy of genres dear to the French literary establishment. His achievement as an essayist must be placed in this broad context of his role as a particularly rebellious Moderne, a Moderne of the avant-garde, in fact; an anticonformist if not a literary anarchist. The keystone of his esthetics was freedom to experiment. (An even more daring 'one-man journal' followed in 1727, the seven issues of L'Indigent philosophe, in which the spokesman is a pauper philosopher, or 'philosopher bum' as Edward Greene calls him in his perceptive analysis of the work, ${ }^{37}$ and which pushes the 'wildness' of the essay ${ }^{38}$ beyond anything Addison or Steele might have imagined.) Marivaux's free-wheeling journalism was part and parcel of his experiments in theatre and fiction. He lived in order to challenge what Oscar Haac calls 'the accepted mold. ${ }^{\prime 39}$ His 'facultés de renouvellement,' in Claude Roy's words, were nourished by 'cette inquiétude créatrice qui le pousse à essayer constamment de nouvelles formes, à inventer des cadres originaux, à ouvrir des voies nouvelles. ${ }^{40}$

The essai journalistique was the first beneficiary of this innovative spirit. In this freeest of forms he abandoned himself 'sans contrôle et sans préoccupation de genre à sa manière propre. ${ }^{41} \mathrm{He}$ used this vehicle, furthermore, to advocate greater freedom, greater libertinage, if one will, in vocabulary ('Il faudrait de nouveaux mots, de nouveaux signes, pour exprimer les nouvelles idées dont cette génération serait capable'), ${ }^{42}$ 
greater freedom in syntax and in imagery. The 'disorder' of many of his sentences (from the purist's point of view, that is; in reality it was a new 'order') offers a microcosm of the orderly disorder of his essays as a whole. Just as in the overall structure of the essay he seems to be straining at the limits of form, so in his new 'stylistique de la suggestion,' as Deloffre calls it, ${ }^{43}$ all the more extraordinary in that it was formulated only a few years after the death of Boileau, he is seen striving to find a language for his own time, a keener linguistic instrument for probing the mysteries of the human heart and of human existence itself. No wonder his contemporaries spoke of the 'metaphysical' quality of his work! Little did most of them suspect, however, what strength lay in this quality.

\section{RICHARD M. CHADBOURNE}

University of Calgary

\section{Notes}

1 This and the other essay works discussed in this paper are quoted from Marivaux, Journaux et oeuvres diverses, ed. F. Deloffre and M. Gilot (Paris: Garnier Frères, 1969). This edition will be referred to henceforth as Journaux.

2 Journaux, 8.

3 Gaston Cayrou, Le Français Classique (Paris: Didier, 1923), pp. 519-20.

4 Journaux, 22.

5 Journaux, 60.

6 Journaux, 570.

7 Deloffre, Marivaux et le marivaudage, une préciosité nouvelle, 2nd ed. (Paris: Armand Colin, 1967), p. 127.

8 Edward Baldwin, 'Marivaux's Place in the Development of Character Portrayal,' PMLA 27 (1912): 169.

9 Journaux, 114.

10 Journaux, 114.

11 Pascal, Pensées, Edition L. Brunschvicg, no. 92.

12 Journaux, 577.

13 Journaux, 114.

14 Mario Mattuci, Marivaux narratore e moralista, quoted in Edward Greene, Marivaux (Toronto: Univ. of Toronto Press, 1965), p. 62.

15 Journaux, 115. 
16 Journaux, 145.

17 Journaux, 148.

18 Journaux, 149.

19 Journaux, 253.

20 Journaux, 8.

21 Giovanni Bonaccorso, 'Le Dialogue de Marivaux avec ses lecteurs,' Cahiers de l'Association Internationale des Etudes Françaises, no. 25 (1973): 209.

22 Bonaccorso, pp. 211-12.

23 Journaux, 117.

24 Journaux, 780.

25 Journaux, 265.

26 Jean Ehrard, 'Marivaux, ou les chemins de la sincérité,' in his Le XVIIIe siècle, I, 1720-1750 (Paris: Arthaud, 1974), pp. 175-6.

27 Ehrard, p. 179.

28 Jean Rousset, 'Marivaux ou la structure du double registre,' in his Forme et signification, Essais sur les structures littéraires de Corneille à Claudel (Paris: 1962), p. 45.

29 Robert Mauzi, 'Marivaux,' in his L'Idée du bonheur dans la littérature et la pensée française au XVIIle siècle, 3rd ed. (1960; rpt. Paris: Armand Colin, 1967), p. 467.

30 Journaux, 110.

31 Pharsamon, quoted in Rousset, p. 50.

32 Journaux, 115.

33 Quoted from Le Mercure, April 1723, in Henri Lagrave, Marivaux et sa fortune littéraire (St.-Médard-en-Jalles: Guy Descros, 1970), p. 20.

34 George Poulet, 'Marivaux,' in his Etudes sur le temps humain, II, La Distance intérieure (Paris: Plon, 1952), p. 10.

35 Poulet, p. 13.

36 Poulet, p. 23.

37 Edward Greene, 'Marivaux's Philosophical Bum,' L'Esprit Créateur 1 (1961), pp. 190-195.

38 Addison's term, in 'On Method in Discourse,' Spectator no. 476. In a foreword to the reader when L'Indigent philosophe finally appeared under his own name, Marivaux described the work as 'un essai de ce qu'on pouvait faire en écrivant au hasard tout ce qui viendrait à l'imagination' - Marivaux, quoted in Henri Coulet and Michel Gilot, Marivaux, un humanisme expérimental (Paris: Libraire Larousse, 1973), p. 87.

39 Oscar Haac, Marivaux (New York: Twayne, 1973), p. 16.

40 Claude Roy, Lire Marivaux (Neuchatel: La Baconnière; Paris: Le Seuil, 1947), p. 118.

41 Deloffre, Marivaux, p. 125.

42 Journaux, 'Le Cabinet du philosophe,' p. 383.

43 Deloffre, Marivaux, p. 144. 